\title{
Perception and knowledge of the Sirex woodwasp and other forest pests in South Africa
}

Brett P. Hurley ${ }^{\mathrm{a}, \mathrm{b}^{*}}$, Jana Slippers ${ }^{\mathrm{c}}$, Michael J. Wingfield ${ }^{\mathrm{b}}$, Colin Dyer ${ }^{\mathrm{d}}$, Bernard Slippers ${ }^{\mathrm{b}, \mathrm{e}}$

${ }^{\mathrm{a}}$ Department of Zoology and Entomology, University of Pretoria, Pretoria, 0002, South Africa; brett.hurley@fabi.up.ac.za

${ }^{\mathrm{b}}$ Forestry and Agricultural Biotechnology Institute, University of Pretoria, Pretoria, 0002, South Africa; mike.wingfield@fabi.up.ac.za

${ }^{\mathrm{c}}$ Department of Marketing and Communication Management, University of Pretoria, Pretoria, 0002, South Africa; jana.slippers@telkomsa.net

${ }^{\mathrm{d}}$ Institute for Commercial Forestry Research, Pietermaritzburg, 3209, South Africa; colin.dyer@icfr.ukzn.ac.za

${ }^{\mathrm{e}}$ Department of Genetics, Forestry and Agricultural Biotechnology Institute, University of Pretoria, Pretoria, 0002, South Africa; bernard.slippers@fabi.up.ac.za

Corresponding author:

Dr B.P. Hurley

FABI, Private Bag X20, Hatfield, Pretoria, 0028, South Africa

Phone: +27 12 4205822; Fax: +27 124203960

Suggested running title: Perception of forest pests

Key words: forest pest management, human dimension, awareness media, survey 


\section{Abstract}

1. Sirex noctilio is one of the most serious invasive pests of pine. In South Africa, there has been a national effort to control S. noctilio, including an awareness campaign to increase awareness of the pest amongst the local forestry community.

2. We considered the impacts that the arrival of the pest and the awareness campaign has had on perceptions and knowledge of $S$. noctilio, as well as other forestry pests, amongst members of the forestry community.

3. For the data collection, a survey questionnaire was developed and used in telephone interviews.

4. Results of the study showed that the Sirex awareness campaign had increased knowledge of forestry pests in general. However, basic knowledge regarding the identification and symptoms of specific pests, such as $S$. noctilio, was poor. This will negatively influence monitoring efficacy.

5. Traditional paper-based media and personal contact contributed most to enhanced awareness. Electronic media were less effective and improvement would require a more focused effort. It was of concern that private farmers and contractors, as well as non-European first language speakers, were less well informed about forestry pests.

6. Clearly, a fragmented landscape in terms of ownership and language, presents challenges for effective communication of forestry pest threats. 


\section{Introduction}

Pests and pathogens pose a serious threat to forestry worldwide. This threat includes both environmental disturbance by altering natural forest habitat, and economic losses, including direct losses to the crop and indirect losses due to the required management interventions (FAO, 2009; Holmes et al., 2009). The increase in global trade and travel has added to this threat by the consequential increase in invasive pests and pathogens (Haack, 2001; Wingfield et al., 2008). These invasions are particularly threatening when pests and pathogens from the native range of the host tree are introduced to environments where these trees are planted as non-natives in plantations. In such cases, the presence of a host monoculture for the pest or pathogen and a lack of their natural enemies provide favourable conditions for their rapid expansion.

In South Africa, a small natural forest resource led to the introduction of nonnative tree species in the eighteenth and nineteenth centuries. Species of Pinus, Eucalyptus and Acacia were thus used to establish plantations to service the demand for wood and wood products (Owen \& van der Zel, 2000). This led to a forestry industry based on non-native trees that occupies about $1 \%$ of the land surface (about 1.3 million ha), produces nearly 18 million tons of roundwood per annum and is a major contributor to the South African economy (Godsmark, 2008). Subsequent to its establishment, the South African forestry industry has been increasingly plagued by invasive pests and pathogens (Wingfield et al., 2008). Of these, the most serious invasive insect of pine has been the Sirex woodwasp, Sirex noctilio F. (Siricidae: Hymenoptera). 
Sirex noctilio is native to Eurasia (Spradbery \& Kirk, 1978), but has been accidentally introduced to the southern hemisphere, where it has become a serious pest of pine species (Hurley et al., 2007), and more recently in the USA and Canada (de Groot et al., 2007; Hoebeke et al., 2005). Subsequent to its detection in South Africa in 1994, S. noctilio spread through three of the main forestry growing provinces. Together with its fungal symbiont Amylostereum areolatum (Basidiomycota), S. noctilio has caused extensive losses to pine, mainly in highly stocked Pinus patula (Pinaceae) stands planted for pulpwood (Hurley et al., 2007).

In 2002, due to increasing infestations of $S$. noctilio in South Africa, a national committee was established and tasked with identifying and implementing appropriate control strategies for $S$. noctilio. This committee included representatives from government, private companies and landowners, and research organizations. An important component of the committee's strategy was to increase the awareness of $S$. noctilio within the forestry community. The human dimension of forest pest disturbance, particularly how the perception and knowledge of stakeholders can influence management success, had been shown in various studies (Flint, 2009; McFarlane \& Witson, 2008; Nyeko et al. 2002), and a high level of awareness of $S$. noctilio was viewed as crucially important to ensure early detection of the pest and to obtain support for the management operations, such as the introduction of biological control agents. Efforts to promote the awareness of $S$. noctilio included information presented at conferences and field days, various forms of paper-based media, and information on the internet. However, the impact that these initiatives have had on the knowledge and perception of $S$. noctilio (and other forestry pests) amongst members of the forestry community is unknown. 
In this study we conducted a questionnaire using telephone interviews to examine the current perception and knowledge of $S$. noctilio and other forest pests, amongst members of the South African forestry community. We furthermore considered how these perceptions were influenced by the socio-demographic characteristics of the respondents. Perception in this study was defined as "a way of understanding or regarding something", and knowledge as "information or skills gained through experience or education; awareness gained by experience of a fact or situation" (Oxford Dictionary of Current English, 2001). We considered four key hypotheses, including: (1) knowledge of $S$. noctilio is positively correlated with knowledge of other forestry pests; (2) perception of the importance of pests influences the basic knowledge of these pests; (3) exposure to elements of the S. noctilio awareness campaign increases knowledge of S. noctilio; (4) socio-demographic characteristics of the respondents, such as job position, work experience, location, mother tongue and importance of major tree genera influence the knowledge and perception of $S$. noctilio and forestry pests in general, as well as which $S$. noctilio awareness media the respondents were exposed to.

\section{Methods}

\section{Survey methods and questionnaire design}

The target population for the survey was those people involved with forestry in South Africa, and who by the nature of their work should be aware of forestry pests. This included private timber growers, contractors, plantation management, researchers and senior management. Administrative staff, nursery staff and those working in paper, 
pulp and saw-timber mills were excluded. The sampling framework for the target population was a list of the relevant employees supplied by companies, government and a co-operative that deals with private farmers. In addition, relevant people in the existing lists of contacts of the Institute for Commercial Forestry Research (ICFR) and the Forestry and Agricultural Biotechnology Institute (FABI) were included. The complete list of people who could be contacted was not entirely comprehensive, but provided sufficient numbers for the sample required.

After the contact list had been assembled, it was refined to exclude invalid numbers and duplicates. The final list amounted to 561 contacts. These contacts were from the main forestry provinces in South Africa, including the Western Cape, Eastern Cape, KwaZulu-Natal, Mpumalanga and Limpopo (Fig. 1). The desired sample size was a minimum of 232 (based on a desired $95 \%$ confidence limit and 5 $\%$ margin of error). Sampling from the list of available contacts was random, but a minimum number of respondents were set for the provinces, namely Western Cape (9), Eastern Cape (9), KwaZulu-Natal (34), Mpumalanga (42) and Limpopo (3). This was based on the proportion of the given contacts living in that province and the importance of the province to forestry.

A questionnaire was prepared to assess the knowledge and perception regarding $S$. noctilio as well as forestry pests in general (Table 1). The questionnaire comprised six main sections: (1) questions to obtain socio-demographic information, namely job position, work experience, location, mother tongue, importance of major forestry species and presence of $S$. noctilio in the working environment; (2) questions pertaining to general pest perception regarding importance of the impact, research and monitoring of forestry pests; (3) questions pertaining to the knowledge of some of the major forestry pests (scientific and common names were given); (4) questions 
pertaining to the exposure of the respondent to different media channels that had been used to increase the awareness of S. noctilio; (5) questions pertaining to knowledge of S. noctilio; and (6) questions pertaining to the perception of $S$. noctilio regarding its control, impact and time required to manage the pest. The questions were preceded by a short introduction that explained the nature and importance of the survey.

The questionnaire consisted of closed questions that were either dichotomous, categorical, multiple choice or scale questions (Table 1). An exception was for the questions that called for the number of years work experience, where the actual number of years was given. Scale questions were from 1-10, where a response of one indicated the lowest and 10 the highest level of importance. Where appropriate, an option for "Don't know" was given. The last question in the section dealing with knowledge of general forestry pests asked whether the respondent was aware of or had heard of $S$. noctilio. Where the response was negative, the questionnaire was terminated as the respondent would not be able to answer questions regarding their knowledge and perception of S. noctilio. However, the information collected concerning their knowledge and perception of forestry pests in general was still used. Thus, this question served as a qualifier to complete the remainder of the interview.

The questionnaire survey was conducted by means of telephone interviews provided by Consulta Research (Pretoria, South Africa). Telephone interviews offer some advantages, in that the study can be completed over a short period, substantial information can be collected within 15 to 30 minutes, there is effective sample control, ambiguities in the responses can be resolved and they have a high response rate (Churchill \& Lacobucci, 2002; Proctor, 2005). Because a pretesting of any questionnaire is vital (Churchill \& Lacobucci, 2002), this was done on five individuals who were not part of the target population. The pre-testing stage 
made it possible to determine the clarity of the questions, particularly concerning the pronunciation of scientific names and the length of the interview, and it ensured that the respondents had a clear understanding of the questions. The interviews were carried out from 15-26 June 2009.

\section{Data editing and analysis}

The data arising from the interviews was edited for errors and incomplete interviews were discarded. Interviews that contained missing fields were not considered. This excluded the interviews that terminated due to the qualifier question (see Survey methods and questionnaire design). Two variables were derived from the dataset. The first derived variable indicated the number of general forestry pests known by the respondent (score out of five; considered as a categorical variable) and the other derived variable indicated the number of correct answers the respondent gave to the questions pertaining to their knowledge of $S$. noctilio (score out of 17 ; considered as a continuous variable). These derived variables were used in subsequent analyses to represent knowledge for general forestry pests and knowledge of S. noctilio, respectively.

Statistical analyses were performed using SAS ver. 8.2 (SAS, 2001). An analysis of variance (ANOVA) using a general linear model (GLM) procedure was used to examine factors that influence the knowledge of $S$. noctilio, specifically sociodemographic characteristics and exposure to different awareness media, where the derived variable (knowledge of $S$. noctilio) was continuous. Logistic regression was used to examine influencing factors where the derived variable was not continuous. This included an examination of how socio-demographic characteristics influenced 
the response to questions pertaining to the perception of $S$. noctilio, exposure to awareness media and knowledge and perception of general forestry pests. A Kendall Tau correlation was used to examine the correlation between knowledge of $S$. noctilio and knowledge and perception of general forestry pests. Descriptive statistics (including mean, standard deviation, standard error and 95\% confidence levels) were calculated to show the perception of general forestry pests and S. noctilio.

Variables were re-categorized for their use in the logistic regression analysis. This was based on an examination of frequency tables, where categories with low frequencies were grouped together. For the job description variable, contractors and private farmers were grouped together and those who responded as 'other' were categorized into an existing group, where appropriate, or they were discarded. Work experience was categorized as five years or less, more than five years but less than 20 years, and 20 years or more. Location was defined based on provinces where $S$. noctilio had been detected and provinces where $S$. noctilio had not been detected. For mother tongue, all languages besides English and Afrikaans were grouped together. All scale questions (1-10) were changed to a binary response where a score of 1-7 was considered as not very important and a score of 8-10 was considered as very important. For the question "How long will it take to manage Sirex below economically important levels", the responses were placed in two categories representing five years or less and more than five years, the later of which included the 'never' responses. Where the respondents provided a 'Don't know' response, for this as well as other questions, these responses were not included in the analyses. 


\section{Results}

\section{Socio-demographic characteristics}

A total of 240 completed interviews were obtained, which gave an error level of $4.8 \%$ at a confidence level of $95 \%$. In terms of demographic characteristics of the respondents, over half (53\%) of the respondents were involved in plantation management, which included foresters, district foresters and area managers (Table 2). The remaining respondents were divided nearly equally between senior management, researchers, and private farmers and contractors. Most of the respondents had been involved in forestry for more than five years. Just over half (55\%) of the respondents were located in a province where $S$. noctilio was present, but only $43 \%$ had $S$. noctilio in the plantation, farm or area in which they worked or for which they had responsibility. This was most likely because some of the respondents residing in areas where $S$. noctilio was present were not involved in pine forestry. Afrikaans (Germanic language most closely related to Flemish and Dutch, spoken in South Africa and Namibia) was the most common language indicated as mother tongue by the respondents (46\%), followed by English (32\%). In total, nine of South Africa's 11 official languages were represented as mother tongue languages of the respondents, with only isiNdebele and Setswana not represented. Other languages included Shona (Zimbabwe and southern Mozambique), Luganda (Uganda) and German. The majority of respondents considered pine and eucalypts as very important, and wattle as not very important to their work. 
Knowledge and perception of general forestry pests

There was a high knowledge of general forestry pests. In this case, $94 \%$ of the respondents knew of at least three of the main forestry pests mentioned, $75 \%$ knew at least four and $45 \%$ knew all of them. Sirex noctilio and Gonipterus scutellatus (Curculionidae, Coleoptera) were the pests that were best known by the respondents, with $98 \%$ and $93 \%$ respectively of the respondents being aware of or having heard of them. Only four of the respondents $(2 \%)$ had never heard of S. noctilio and they were, therefore, unable to continue with the questions pertaining to their knowledge and perception of S. noctilio. Whitegrubs (larvae of native Scarabaeidae, Coleoptera), Leptocybe invasa (Eulophidae, Hymenoptera) and Thaumastocoris peregrinus (Thaumastocoridae, Hemiptera) were not as well-known as S. noctilio and G. scutellatus, with $77 \%, 74 \%$ and $70 \%$ respectively, of the respondents being aware of or having heard of them. How important the respondents considered eucalypts for their work significantly influenced their knowledge of general forestry pests $(p=$ $0.02, \mathrm{df}=1)$. Thus, those respondents who considered eucalypts to be very important in their work were more likely to have a greater knowledge of general forest pests. This is most likely because most of the pests mentioned in the survey were pests of eucalypts. None of the other socio-demographic characteristics significantly influenced the knowledge of general forestry pests (Table 3).

The majority of respondents considered the impact of forestry pests on plantation forestry in South Africa to be very important (mean score $=8.3$, SD = 1.7). Research on forestry pests and monitoring for forestry pests were perceived to be very important for their control (mean score $=9.0,9.0, \mathrm{SD}=1.3,1.4$, respectively). The level to which respondents considered pine and eucalypts important to their work 
significantly influenced their perception of the importance of the impact of forestry pests (Table 3). Here, those who considered pine and eucalypts to be very important to their work were more likely to consider the impact of forestry pests as very important.

The mother tongue of the respondent significantly influenced their perception on the importance of research on forestry pests (Table 3 ). Those whose mother tongue was Afrikaans or English were more likely to consider research on forestry pests as very important. None of the other socio-demographic characteristics significantly influenced the perception of general forestry pests. Those who perceived research on forestry pests to be very important were more likely to have a greater knowledge of general forestry pests than those that did not consider research on forestry pests as very important $(p=0.04, d f=1)$.

\section{Sirex awareness media}

Results showed that most of the media avenues used to increase awareness of $S$. noctilio had provided a high degree of exposure (Table 4). All the different media tools, except conferences and the internet / websites, had reached over $80 \%$ of the respondents. Only $67 \%$ of the respondents had heard of S. noctilio at a conference and only $51 \%$ of the respondents were informed of S. noctilio through the internet / website. Respondents also indicated they had been exposed to $S$. noctilio via emails, 'word of mouth', personal communication with staff of the ICFR and TPCP (Tree Protection Cooperative Programme), internal meetings / communications, studies at tertiary institutions, or that they had seen $S$. noctilio themselves. 
Certain socio-demographic characteristics significantly influenced whether respondents had been exposed to some of the awareness media (Table 3). Job position significantly influenced whether the respondent was exposed to $S$. noctilio through posters, pamphlets or pests identification cards and conferences. Work experience significantly influenced whether a respondent had been exposed to knowledge of $S$. noctilio through pamphlets or pest identification cards. Furthermore, geographic location of the respondents significantly influenced whether they had been exposed to S. noctilio through magazines or newspapers and field days. Those involved in plantation management were more likely to have been made aware of S. noctilio through posters, followed by senior management, researchers and private farmers and contractors. Private farmers and contractors, and those with the least work experience were the least likely to have been exposed to $S$. noctilio through pamphlets or pest identification cards. Researchers were the most likely to have been exposed to $S$. noctilio at conferences and by other types of media (listed above), followed by senior management, plantation management, and private farmers and contractors. Those living in a province where $S$. noctilio was present were more likely to have been exposed to knowledge of $S$. noctilio through magazines and newspapers or at field days. The mother tongue of the respondent did not significantly influence their exposure to any of the media (Table 3).

Knowledge and perception of S. noctilio

Of the 17 questions asked to assess the knowledge of $S$. noctilio, the average number of correct answers from the respondent was $12.1(71 \%)(\mathrm{SD}=3.1$; range $=3-17)$. Most of the respondents had a basic knowledge of the trees infested by S. noctilio 
(pine) and the age of trees infested (generally above seven years old), but knowledge regarding the identification of $S$. noctilio and symptoms of infestation were poor (below 50\% of the respondents) (Table 5). Regarding the distribution of S. noctilio, most respondents answered correctly that $S$. noctilio had been detected in the Western Cape, Eastern Cape and KwaZulu-Natal and not yet reached Limpopo. However, only $40 \%$ of the respondents answered correctly that $S$. noctilio had not been detected in Mpumalanga at the time that the survey was conducted (Table 5). Most of the respondents knew that $S$. noctilio could spread by natural flight, round wood, and on wooden pallets, but only $60 \%$ of respondents knew that $S$. noctilio could not spread via the movement of bark (Table 5). Most of the respondents were aware that parasitic nematodes and plantation management were being used to control S. noctilio in South Africa, but less (65\%) knew that parasitic wasps are also used (Table 5).

Knowledge of $S$. noctilio was significantly influenced by the job position and mother tongue of the respondent (Table 6). Private farmers and contractors and those whose mother tongue was not Afrikaans or English had significantly less knowledge of $S$. noctilio. Exposure to $S$. noctilio awareness media significantly influenced knowledge of S. noctilio for all the media except articles in ICFR / TPCP newsletters and internet / website, where those exposed to these media had a greater knowledge of S. noctilio than those who were not (Table 6). There was a significant positive correlation, although weak, between the knowledge of S. noctilio and knowledge of general forestry pests $\left(\mathrm{r}_{\mathrm{k}}=0.32, \mathrm{p}<0.0001\right)($ Table 7$)$. There was no correlation between knowledge of $S$. noctilio and the perception of general forestry pests, relating to the importance of their impact, importance of research and importance of monitoring (Table 7). 
Perception regarding the importance of using parasitic nematodes, parasitic wasps and plantation management to control $S$. noctilio was very high (score of above 8 on a scale of 1-10) (Fig. 2). The use of parasitic nematodes was, on average, perceived to be most important and the use of parasitic wasps the least important, but these differences were not significant. Sirex noctilio was perceived as a very serious problem for both current and future forest productivity in South Africa (score of above 8 on a scale of 1-10) (Fig. 2). The perceived threat to future productivity was slightly higher, but this difference was not significant. The majority of the respondents thought that $S$. noctilio would be managed below economically important levels within the next five years $(42 \%)$ or in more than five years $(48 \%)$. Only $3 \%$ thought that $S$. noctilio would be managed below economically important levels within the next year and only $2 \%$ thought that $S$. noctilio would never be managed below economically important levels. The remaining 5\% did not know when $S$. noctilio would be managed below economically important levels.

The perception of $S$. noctilio was influenced by certain socio-demographic characteristics of the respondents (Table 3). Job position significantly influenced the perception of how important plantation management was to control S. noctilio, the threat of $S$. noctilio to future forest productivity and the time needed to control $S$. noctilio below economically important levels. The perceived importance of plantation management was highest for plantation managers, then for researchers, private farmers and contractors, and lowest for senior management. Plantation managers were more likely to consider the threat of $S$. noctilio to future forest productivity as very high, and this level of importance was perceived as progressively lower by private farmers and contractors, researchers and senior management. Researchers were most likely to consider that $S$. noctilio would be controlled below economically important 
levels in five years or less (68\% of researchers), followed by senior management (50\%), plantation management (46\%) and private farmers and contractors $(28 \%)$. The importance of pine in their work significantly influenced the perception of the threat of $S$. noctilio to current and future forest productivity. Those respondents that considered pine very important in their work were more likely to consider the threat of $S$. noctilio to current and future forest productivity as very high. The importance of eucalypts in their work also significantly influenced the perception of the threat of $S$. noctilio to future forest productivity. Thus, those respondents that considered eucalypts very important in their work were more likely to consider the threat of $S$. noctilio to future forest productivity as very important.

\section{Discussion}

This study examined perception and awareness (knowledge) of S. noctilio and general forest pests in South African forestry, and how these are influenced by various sociodemographic factors relevant to this community. The results showed that: (1) knowledge of $S$. noctilio was positively correlated with knowledge of pests in general; (2) perception regarding pests in general did influence the knowledge of these pests; (3) exposure to $S$. noctilio awareness media increased knowledge of S. noctilio; (4) socio-demographic characteristics influence the knowledge and perception of $S$. noctilio and forestry pests in general, as well as the exposure to S. noctilio awareness media. A closer examination of the results revealed various successes and failures in efforts to increase awareness of $S$. noctilio in the forestry community. They also provided useful information on how a serious pest threat and efforts to control it can 
influence the knowledge and perception amongst members of the affected community.

Knowledge of general forestry pests and S. noctilio

Awareness of the most important forestry pests was relatively high, but it should be more acute, considering that the pests listed can cause serious losses. Besides $S$. noctilio, G. scutellatus was the pest that most respondents were aware of. Gonipterus scutellatus is an invasive pest of Eucalyptus, native to Australia, which was first detected in South Africa in 1916 (Tooke, 1955). Its presence as a serious pest of various Eucalyptus species for nearly 100 years in South Africa explains why this insect is very well known. Thaumastocoris peregrinus and L. invasa are also serious invasive pests of Eucalyptus spp., but their appearance in South Africa has been much more recent, which probably explains why these pests are not as well-known as $G$. scutellatus. Thaumastocoris peregrinus was first detected in South Africa in 2003, and on plantation Eucalyptus in 2005 (Jacobs \& Nesser, 2005; Nadel et al., 2010), and L. invasa was first detected in 2007,and on plantation Eucalyptus in 2009 (authors, personal communication). Whitegrubs are larvae of native Scarabeiidae beetles and are pests of various plants, including forestry species (Govender, 2007). Insecticides can be used to control whitegrubs which has possibly reduced the pest status and awareness of these insects.

Almost all respondents were aware of $S$. noctilio. This included people from different geographic locations, work experience, home language and differing importance of pine in their work environment. This can most likely be attributed to the major economic threat that S. noctilio poses for forestry in South Africa (Hurley et 
al., 2007). Consequently, the publicity that it has received, in media such as those considered in this study, including posters and pamphlets, field days, as well as word of mouth and other media, has been a vehicle to disseminate information.

Although awareness of $S$. noctilio was very high, it was of concern that there was a low basic knowledge regarding characteristics needed to identify the insect and symptoms associated with its damage. It is important that those involved in forestry are able to identify $S$. noctilio and its symptoms in order to ensure early detection of $S$. noctilio in new areas of infestation. This will ensure that management strategies can be established when the population of the insect is still low (Haugen et al., 1990). Clearly, future efforts to disseminate information regarding $S$. noctilio will need to focus on identification of the insect and symptoms associated with infestation.

Parasitic wasps have been used to a lesser extent than parasitic nematodes to manage $S$. noctilio populations. This must explain why control based on the use of these parasitoids was less well known. The confusion surrounding the current distribution of $S$. noctilio was to be expected as $S$. noctilio had been detected on the border of Mpumalanga at the time of the survey. This explains why many of the respondents thought that $S$. noctilio was already in that Province. A lack of accurate knowledge regarding the distribution of the insect can, however, affect the spread of the insect if people move infested wood because they perceive the insect to already be present in an area. This is a matter that will require attention in the future.

Perception of forestry pests and how this influences general pest knowledge

The impact that forestry pests have on plantation productivity, as well as the importance of research and monitoring aimed at their control was perceived as very 
important. This reflects the seriousness of pest infestations in South African plantation forestry. Sirex noctilio alone was estimated to result in approximately R300 million losses per annum to the forestry industry during its peak in the KwaZulu-Natal province (Hurley et al., 2007). Infestations of G. scutellatus are increasing. Thaumastocoris peregrinus has spread rapidly through South Africa and is now considered one of the main pests of Eucalyptus (Nadel et al., 2010). Likewise, L. invasa, although only recently detected in plantations, poses a serious threat to Eucalyptus forestry. Three of these invasive pests have been detected in the last 15 years and indications are that the rate of appearance of new invasive pests is increasing with time (Wingfield et al., 2008). The seriousness of native pest infestations is also increasing with the cossid moth, Coryphodema tristis (Cossidae, Lepidoptera) causing extensive losses of E. nitens (Boreham, 2006; Gebeyehu et al., 2005). Infestations of these pests are particularly serious as in most cases effective control measures are not available.

The perception that people have of pests can influence their knowledge of pests in general. Our study showed that those respondents that perceived research on forestry pests and their control to be very important had a better knowledge of forestry pests. However, this influence was only marginally significant and the perception of the impact of forestry pests and monitoring aimed at controlling them did not significantly influence general pest knowledge.

Exposure to S. noctilio awareness media

Awareness campaigns provide an effective means to support the management of pests and to share information regarding their impact (Garcia-Llorente et al., 2008). Heong 
et al. (1998; 2008) for example showed how different forms of communication, including radio broadcasts, information posters and leaflets, can be used effectively to alter management practices. The results of the present study indicate that the media used to increase awareness of $S$. noctilio has largely been effective in reaching members of the forestry community and significantly increased the knowledge of the pest. In particular, posters, pamphlets / pest identification cards, ICFR / TPCP newsletters, and magazines and newspaper articles have had a high level of penetration into the forestry community and they have effectively increased knowledge of $S$. noctilio.

Conferences and the internet or websites were the least effective media to inform people about $S$. noctilio. Conferences are generally not attended by members of all sectors of the forestry community and only a limited number of people can attend these meetings due to restricted costs and time constraints. The poor reach of the internet or websites in promoting awareness of $S$. noctilio is possibly because many members of the forestry community do not have frequent access to the internet. Furthermore, at the time of the survey there was no website that provided a good source of information on S. noctilio. Although online advertising in South Africa recorded the fastest growth rate from all English-language countries in 2008, there is still a very slow growth in internet access, with only $8 \%$ of the population estimated to have internet connection in 2007 (www.worldwideworx.com). An informative website on $S$. noctilio has recently been developed that is specifically targeted at the forestry community in South Africa (http://www.icfr.ukzn.ac.za/collaboration/sirex). This is expected to increase knowledge of $S$. noctilio among those that have internet connections, but it will not assist those people without access to the internet. 
A medium to promote knowledge of $S$. noctilio that could be very successful is the mobile phone. The use of mobile phones is increasing globally, including in Africa, and they are replacing land lines as the preferred means of communication (Hodge, 2005). Most people in South Africa have a mobile phone (Esselaar \& Stork, 2005), and penetration using this medium will be high. Forms of communication will be much more limited, but potentially simple alerts with attached images could be dispatched, with the recipient directed to a contact number or website for more information should they suspect the presence of the pest in their area. This could be particularly useful in monitoring the spread of newly discovered pests.

\section{Influence of socio-demographic characteristics}

The influence of socio-demographic characteristics on the knowledge and perception of pests and other invasive species has been clearly shown in various studies (Chang et al., 2009; Garcia-Llorente et al., 2008; McFarlane et al., 2006; Nyeko et al., 2002; Obopile et al., 2008). The influence of socio-demographic characteristics on the exposure to awareness media is also important because these media make it possible to develop the knowledge and perception of a problem amongst members of a given community. This survey exposed the negative issue that private farmers and contractors were shown to have the least exposure to awareness media and the lowest knowledge of $S$. noctilio. This was not because of the importance of pine to these farmers and contractors, as this variable was not found to significantly influence exposure to awareness media or knowledge of S. noctilio. Rather, it appears that the media used to promote awareness regarding S. noctilio have not penetrated this sector 
of the forestry community as successfully as others, and this has resulted in the lower level of knowledge regarding S. noctilio.

Posters, pamphlets / pest identification cards and conferences were the particular media that failed to reach private farmers and contractors effectively. This weakness will need to be addressed in the future. The forestry sector in South Africa is currently undergoing significant, and government supported transformation (see http://www2.dwaf.gov.za/webapp/ProjectsBBBEE.aspx), which will continue to increase private ownership. The lack of awareness in this sector evident from this survey is consequently of particular concern.

Respondents of this survey whose mother tongue was neither English nor Afrikaans had a lower level of knowledge concerning S. noctilio. Furthermore, they considered the importance of research for the control of forestry pests as less important than those whose mother tongue was English or Afrikaans. The lower level of knowledge regarding S. noctilio was not due to the awareness media having been in English or Afrikaans, as mother tongue did not significantly influence exposure to awareness media. This result might at least partially be explained due to the higher percentage of private farmers and contractors that were included in this group of respondents (Table 8). Furthermore, the surveys were conducted in English with an option for Afrikaans, but not for the other languages spoken in South Africa, and this could have influenced how well the questions pertaining to the knowledge of $S$. noctilio were understood. The reason for why this group considered research for the control of forestry pests to be less important is unclear, and this difference was only marginally significant. The future transformation of ownership in the South African forestry industry will increase the number of non-English and non-Afrikaans speaking 
people owning plantations. Thus, home language will need to be more carefully considered in future awareness campaigns.

Four of the five pests mentioned in the general pest knowledge section of the questionnaire were pests of Eucalyptus. This explains why those respondents who considered Eucalyptus as very important in their work scored a higher knowledge of general forestry pests. These four pests and S. noctilio, which attack pine, have a serious impact on forest productivity (see Perception of forestry pests and how this influences general pest knowledge). This then explains why the impact of forestry pests was perceived as higher by those who considered eucalypts and pine as very important in their work. The importance of wattle did not influence the perception of forestry pests in general. This was possibly because insect pests on wattle do not currently pose as serious a threat as do those on pine and eucalypts. Not surprisingly, those respondents that considered pine as very important also perceived the use of parasitic nematodes as biological control agents and the threat of $S$. noctilio as very important.

Interestingly, geographic location of respondents did not influence perception or knowledge of forestry pests in general or S. noctilio. It would have been expected that the perception and knowledge of $S$. noctilio would differ between areas where $S$. noctilio is present and those where the pest is absent, but this was not the case. This is in contrast to for instance the study of McFarlane et al. (2006) where public living near the mountain pine beetle (Dendroctonus ponderosae (Curculionidae, Coleoptera)) outbreaks had a more informed view of the pest and they were also more likely to support efforts to control it. The lack of location effect on the knowledge and perception of $S$. noctilio is likely because it is a national threat to forestry and because efforts have been made to distribute information to all forestry areas. 


\section{Conclusion}

The South African forestry community regards the threat of S. noctilio and other forestry pests, and the need to control them as extremely important. The national programme to increase the awareness of $S$. noctilio amongst members of the forestry community has largely been effective in increasing the knowledge of the pest. This will consequently increase chances of early detection of $S$. noctilio in new areas of infestation and increase the support for management operations. This result demonstrates the value of a nationally co-ordinated awareness campaign.

Where the awareness campaign failed was in its ability to reach private farmers and contractors. This demonstrates the affect that a fragmented and diverse forestry community poses for communication and, therefore, pest management. Pest management in the future will need to consider more effective means of communication in order to effectively reach all the sectors of the forestry community. The diversity of languages spoken amongst the target group also needs to be considered and there could be value in conducting marketing research to better understand this and other aspects of the target group. 


\section{Acknowledgements}

We thank Prof. Hennie Groeneveld and Dr. Mike van der Linde (Department of Statistics, University of Pretoria) for their assistance with the survey design and statistical analyses. Mr Philip Croft (National Sirex Co-ordinator, ICFR) also provided invaluable advice regarding the questionnaire used in the survey. We also thank Lies1 Pearson (Consulta Research) for her efforts to ensure that the telephonic interviews were effective. We are most grateful to Dr. Ilaria Germishuizen (ICFR) for providing the map used in Fig. 1. The National Sirex Steering Committee of South Africa provided invaluable support including contact details, without which this survey could not have been conducted. We are especially grateful to our many forestry colleagues who participated and supported the survey. Forestry South Africa (FSA), the Department of Water Affairs and Forestry, the University of Pretoria and the THRIP initiative of the Department of Trade and Industry (DTI), South Africa, provided financial support for this study. 


\section{References}

Boreham, G.R. (2006) A survey of cossid moth attack in Eucalyptus nitens on the Mpumalanga Highveld of South Africa. Southern African Forestry Journal, 206, 23-26.

Chang, W-Y., Lantz, V.A. \& MacLean, D.A. (2009) Public attitudes about forest pest outbreaks and control: Case studies in two Canadian provinces. Forest Ecology and Management, 257, 1333-1343.

Churchill, G.A. \& Lacobucci, D. (2002) Marketing research: methodological foundations. Eighth Edition. Harcourt College Publishers, Fort Worth.

de Groot, P., Nystrom, K. \& Scarr, T. (2007) Discovery of Sirex noctilio (Hymenoptera: Siricidae) in Ontario, Canada. Great Lakes Entomologist, 39, $49-53$.

Esselaar, S. \& Stork, C. (2005) Mobile cellular telephone: Fixed-line substitution in sub-Saharan Africa. The Southern African Journal of Information and Communication, 6, 64-73.

FAO. (2009) Global review of forest pests and diseases. FAO Forestry Paper 156, Rome.

Flint, C.G., McFarlane, B.L., \& Müller, M. (2009) Human dimensions of forest disturbance by insects: An international synthesis. Environmental Management, 43, 1174-1186.

García-Llorente, M., Martín-López, B., González, J.A., Alcorol, P. \& Montes, C. (2008) Social perceptions of the impacts and benefits of invasive alien species: Implications for management. Biological Conservation, 141, 2969-2983. 
Gebeyehu, S., Hurley, B.P. \& Wingfield, M.J. (2005) A new lepidopteran insect pest discovered on commercially grown Eucalyptus nitens in South Africa. South African Journal of Science, 101, 26-28.

Godsmark, R. (2008) The South African forestry and forest products industry 2007. Forestry South Africa, www.forestry.co.za.

Govender, P. (2007) Status of seedling establishment pests of Acacia mearnsii De Wild. (Mimosaceae) in South Africa. South African Journal of Science, 103, 141-147.

Haack, R.A. (2001) Intercepted Scolytidae (Coleoptera) at U.S. ports of entry: 19852000. Integrated Pest Management Reviews, 6, 253-282.

Haugen, D.A., Bedding, R.A., Underdown, M.G. \& Neumann, F.G. (1990) National strategy for control of Sirex noctilio in Australia. Australian Forest Grower, 13, No. 2.

Heong, K.L., Escalada, M.M., Huan, N.H. \& Mai, V. (1998) Use of communication media in changing rice farmers' pest management in the Mekong Delta, Vietnam. Crop Protection, 17, 413-425.

Heong, K.L., Escalada, M.M., Huan, N.H., Ky Ba, V.H., Quynh, P.V., Thiet, L.V. \& Chien, H.V. (2008) Entertainment-education and rice pest management: A radio soap opera in Vietnam. Crop Protection, 27, 1392-1397.

Hodge, J. (2005) Tariff structures and access substitution of mobile cellular for fixed line in South Africa. Telecommunications Policy, 29, 493-505.

Hoebeke, E.R., Haugen, D.A. \& Haack, R.A. (2005) Sirex noctilio: discovery of a Palearctic siricid woodwasp in New York. Newsletter of the Michigan Entomological Society, 50, 24-25. 
Holmes, T.P., Aukema, J.E., Von Holle, B., Liebhold, A. \& Sills, E. (2009) Economic impacts of invasive species in forests: Past, present and future. Annals of the New York Academy of Science, 1162, 18-38.

Hurley, B.P., Slippers, B. \& Wingfield, M.J. (2007) A comparison of control results for the alien invasive woodwasp, Sirex noctilio, in the southern hemisphere. Agricultural and Forest Entomology, 9, 159-171.

Jacobs, D.H. \& Nesser, S. (2005) Thaumatocoris australicus Kirkaldy (Heteroptera: Thaumastocoridae): a new insect arrival in South Africa, damaging to Eucalyptus trees. South African Journal of Science, 101, 233-236.

McFarlane, B.L., Stumpf-Allen, R.C.G. \& Watson, D.O. (2006) Public perceptions of natural disturbance in Canada's national parks: The case of the mountain pine beetle (Dendroctonus ponderosae Hopkins). Biological Conservation, 130, $340-348$.

McFarlane, B.L., \& Watson, D.O. (2008) Perceptions of ecological risk associated with mountain pine beetle (Dendroctonus ponderosae) infestations in Banff and Kootenay National Parks of Canada. Risk Analysis, 28, 203-212.

Nadel, R.L., Slippers, B., Scholes, M.C., Lawson, S.A., Noack, A.E., Wilcken, C.F., Bouvet, J.P. \& Wingfield, M.J. (2010) DNA bar-coding reveals source and patterns of Thaumastocoris peregrinus invasions in South Africa and South America. Biological Invasions, 12, 1067-1077.

Nyeko, P., Edwards-Jones, G., Day, R.K. \& Raussen, T. (2002) Farmers' knowledge and perceptions of pests in agroforestry with particular reference to Alnus species in Kabale district, Uganda. Crop Protection, 21, 929-941. 
Obopile, M., Munthali, D.C. \& Matilo, B. (2008) Farmers' knowledge, perceptions and management of vegetable pests and diseases in Botswana. Crop Protection, 27, 1220-1224.

Owen, D.L. \& van der Zel, D.W. (2000) Trees, forests and plantations in Southern Africa. South African Forestry Handbook 2000 (ed. by D.L. Owen), pp. 3-7. South African Institute of Forestry, South Africa.

Oxford Dictionary of Current English. (2001) Third Edition. Oxford University Press, New York.

Proctor, T. (2005) Essentials of Marketing Research. Fourth Edition. Prentice Hall, Harlow.

SAS Institute. (2001) Users Guide. SAS Institute Inc., Cary NC, USA.

Spradbery, J.P. \& Kirk, A.A. (1978) Aspects of the ecology of siricid woodwasps (Hymenoptera: Siricidae) in Europe, North Africa and Turkey with special reference to the biological control of Sirex noctilio F. in Australia. Bulletin of Entomological Research, 68, 341-359.

Tooke, F.G.C. (1955) The Eucalyptus snout beetle, Gonipterus scutellatus Gyll: A study of its ecology and control by biological means. Entomology Memoirs 3. Department of Agriculture, Pretoria, South Africa.

Wingfield, M.J., Slippers, B., Hurley, B.P., Coutinho, T.A., Wingfield, B.D. \& Roux, J. (2008) Eucalypt pests and diseases: Growing threats to plantation productivity. Southern Forests, 70, 139-144. 
Table 1. Summary of survey questions

\section{Socio-demographic information}

Which one of the following describes your position the best?

How many years have you been involved in forestry?

6 categories $^{a}$

Continuous

In which province do you work or are based in for the majority of time?

What is your mother tongue?

9 provinces

11 official languages

Indicate the importance of the following exotic tree species for your work: Scale $(1-10)^{\mathrm{b}}$

pine, eucalypts, wattle

Do you have Sirex in the area that you work in or are responsible for? Yes / No

\section{General pest perception}

How important do you consider the impact of forestry pests on plantation Scale $(1-10)^{\mathrm{b}}$

productivity in South Africa?

How important do you consider research on forestry pests for their control?

Scale $(1-10)^{\mathrm{b}}$

How important do you consider monitoring for the presence of forestry

pests for their control?

Scale $(1-10)^{b}$

\section{General pest knowledge}

Which of the following forestry pests in South Africa are you aware of or Yes / No have heard of: Thaumastocoris peregrinus, Leptocybe invasa, Gonipterus scutellatus, whitegrubs, Sirex noctilio? (common names were also given)

\section{Exposure to awareness media}

Were you informed of Sirex through: posters; pamphlets or pest cards; articles in ICFR / TPCP newsletters; internet or website; magazines or newspapers; field days; conferences; other?

\section{Sirex knowledge}

(17 questions relating to knowledge on the identification, symptoms of attack, distribution and means of spread and control)
Multiple choice, Yes / No ${ }^{b}$

Scale $(1-10)^{b}$

Scale $(1-10)^{b}$

5 categories $^{c}$

\section{Sirex perception}

How important are the control measures: parasitic nematodes; parasitic wasps; plantation management?

How serious a problem is Sirex for forest productivity in South Africa (current and future)?

How long will it take to manage Sirex below economically important levels in South Africa?

Yes / $\mathrm{No}^{\mathrm{b}}$

${ }^{a}$ contractor, private farmer, plantation management, researcher, senior management, other brespondants were also given the option "Don't know"

c within the next year; within the next five years; more than five years; never; don't know 
Table 2. Socio-demographic characteristics of sample population

\begin{tabular}{|c|c|c|}
\hline Socio-demographic characteristic & Category & $\begin{array}{l}\% \text { of sample } \\
\text { population }\end{array}$ \\
\hline \multirow[t]{4}{*}{ Job position } & Private farmers / contractors ${ }^{a}$ & 15 \\
\hline & Plantation management & 53 \\
\hline & Researcher & 14 \\
\hline & Senior management & 18 \\
\hline \multirow[t]{3}{*}{ Work experience ${ }^{b}$} & Five or less years & 15 \\
\hline & More than five years & 47 \\
\hline & More than 20 years & 38 \\
\hline \multirow[t]{2}{*}{ Location } & In Sirex-infested area ${ }^{c}$ & 55 \\
\hline & Not in Sirex-infested area ${ }^{d}$ & 45 \\
\hline \multirow[t]{3}{*}{ Mother tongue } & English & 32 \\
\hline & Afrikaans & 46 \\
\hline & Othere & 22 \\
\hline \multirow[t]{2}{*}{ Importance of pine } & Very important ${ }^{\mathrm{f}}$ & 79 \\
\hline & Not very important ${ }^{g}$ & 21 \\
\hline \multirow[t]{2}{*}{ Importance of eucalypts } & Very important ${ }^{f}$ & 70 \\
\hline & Not very important ${ }^{9}$ & 30 \\
\hline \multirow[t]{2}{*}{ Importance of wattle } & Very important ${ }^{f}$ & 21 \\
\hline & Not very important ${ }^{9}$ & 79 \\
\hline \multirow[t]{2}{*}{ Presence of Sirex in working area } & Yes & 43 \\
\hline & No & 57 \\
\hline
\end{tabular}

${ }^{a}$ private farmers and contractors were combined for analyses

byears of work experience grouped into three categories for analyses

${ }^{c}$ Western Cape, Eastern Cape, KwaZulu-Natal

${ }^{\mathrm{d}}$ Mpumalanga, Limpopo, Gauteng, Free State

eisiXhosa, isiZulu, Sepedi, Sesotho, Siswathi, Tshivenda, Xitsonga, Shona, Luganda, German

fscore of 1-7

${ }^{9}$ score of 8-10 
Table 3. Influence of socio-demographic characters on perception of $S$. noctilio, exposure to awareness media, general pest knowledge and general pest perception. Results are from logistic regression analysis, where the dependant variables were categorical.

\section{General pest knowledge}

\section{General pest perception}

Impact of forestry pests

Research on forestry pests

Monitoring of forestry pests

\section{Exposure to awareness media}

\section{Posters}

Pamphlets or pest cards

Articles in TPCP / ICFR newsletters

Internet or website

Magazines or newspapers

Field days

Conferences

Other

\section{Sirex perception}

Importance of nematodes for control

Importance of wasps for control

Importance of plantation management for control

Current threat of Sirex

Future threat of Sirex

Time needed to control Sirex

*significant at $5 \%$ level, $p<0.05$

** significant at $1 \%$ level, $p<0.01$

${ }^{* * *}$ significant at $0.1 \%$ level, $p<0.001$

Socio-demographic characters

\begin{tabular}{llllllll}
$\begin{array}{l}\text { Job } \\
\text { position }\end{array}$ & $\begin{array}{l}\text { Work } \\
\text { experience }\end{array}$ & Location & $\begin{array}{l}\text { Home } \\
\text { language }\end{array}$ & $\begin{array}{l}\text { Importance } \\
\text { of pine }\end{array}$ & $\begin{array}{l}\text { Importance } \\
\text { of eucalypts }\end{array}$ & $\begin{array}{l}\text { Importance of Presence of Sirex } \\
\text { wattle }\end{array}$ & $\begin{array}{l}\text { leodwasp in working } \\
\text { area }\end{array}$ \\
\hline 0.1 & 0.9 & 0.06 & 0.5 & 0.8 & $0.02^{*}$ & 0.1 & 0.8 \\
& & & & & & & \\
0.5 & 0.7 & 0.7 & 0.8 & $0.03^{*}$ & $0.03^{*}$ & 0.6 & 0.1 \\
0.6 & 0.2 & 0.4 & $0.04^{*}$ & 0.3 & 0.6 & 0.1 & 0.4 \\
0.5 & 0.6 & 0.5 & 0.07 & 0.3 & 0.2 & 0.1 & 0.7
\end{tabular}

$\begin{array}{llllllll}0.003^{* *} & 0.7 & 0.9 & 0.1 & \text { NA } & \text { NA } & \text { NA } & \text { NA } \\ 0.008^{* *} & 0.0001^{* * *} & 0.8 & 0.1 & \text { NA } & \text { NA } & \text { NA } & \text { NA } \\ 0.1 & 0.3 & 0.8 & 0.1 & \text { NA } & \text { NA } & \text { NA } & \text { NA } \\ 0.2 & 0.4 & 0.9 & 0.9 & \text { NA } & \text { NA } & \text { NA } & \text { NA } \\ 0.2 & 0.1 & 0.03^{*} & 0.5 & \text { NA } & \text { NA } & \text { NA } & \text { NA } \\ 0.3 & 0.9 & 0.02^{*} & 0.3 & \text { NA } & \text { NA } & \text { NA } & \text { NA } \\ 0.0002^{* * *} & 0.9 & 0.7 & 0.8 & \text { NA } & \text { NA } & \text { NA } & \text { NA } \\ 0.05^{*} & 0.9 & 0.8 & 0.4 & \text { NA } & \text { NA } & \text { NA } & \text { NA }\end{array}$

$\begin{array}{llllllll}0.4 & 0.4 & 0.4 & 0.9 & 0.02^{*} & 0.6 & 0.8 & \text { NA } \\ 0.3 & 0.6 & 0.7 & 0.5 & 0.8 & 0.1 & 0.2 & \text { NA } \\ 0.01^{* *} & 0.9 & 0.6 & 0.1 & 0.3 & 0.3 & 0.2 & \text { NA } \\ 0.2^{*} & 0.9 & 0.08 & 0.3 & 0.004^{* *} & 0.07 & 0.2 & \text { NA } \\ 0.05^{\star} & 0.06 & 0.7 & 0.7 & 0.0004^{\star * *} & 0.01^{* *} & 0.2 & \text { NA } \\ 0.03^{*} & 0.7 & 0.7 & 0.3 & 0.8 & 0.3 & 0.3 & \text { NA }\end{array}$


Table 4. Exposure of respondents to $S$. noctilio awareness media.

\begin{tabular}{ll} 
Awareness media & $\begin{array}{l}\% \text { of sample } \\
\text { population }\end{array}$ \\
\hline Conferences & 67 \\
Field days & 90 \\
Magazines / newspapers & 86 \\
Internet / websties & 51 \\
ICFR / TPCP newsletters & 89 \\
Pamphlets / pest cards & 86 \\
Posters & 84
\end{tabular}

Table 5. Knowledge of respondents on questions pertaining to the identification, symptoms, distribution, and means of spread and control of $S$. noctilio.

\begin{tabular}{|c|c|c|}
\hline Category & Sub-category & $\begin{array}{l}\% \text { of sample } \\
\text { population }\end{array}$ \\
\hline \multirow[t]{3}{*}{ Control of S. noctilio by: } & Plantation management & 80 \\
\hline & Parasitic wasps & 65 \\
\hline & Parasitic nematodes & 90 \\
\hline \multirow[t]{4}{*}{ Spread of S. noctilio by: } & Bark & 60 \\
\hline & Pallets & 79 \\
\hline & Roundwood & 93 \\
\hline & Flight & 89 \\
\hline \multirow[t]{5}{*}{ Presence of S. noctilio in: } & Limpopo & 72 \\
\hline & Mpumalanga & 40 \\
\hline & KwaZulu-Natal & 95 \\
\hline & Eastern Cape & 77 \\
\hline & Western Cape & 79 \\
\hline \multirow[t]{5}{*}{ Recognizing S. noctilio infestation by: } & Tree symptom & 47 \\
\hline & Larval characteristic & 42 \\
\hline & Wasp colour & 31 \\
\hline & Tree age & 78 \\
\hline & Tree species & 97 \\
\hline
\end{tabular}


Table 6. Factors affecting knowledge of $S$. noctilio. Results from ANOVA using general linear model, where dependant variable was continuous.

\begin{tabular}{llll} 
Variable & df & F value & p value \\
\hline Socio-demographic characteristics & & & \\
Job position & 3 & 10.03 & $<.0001^{* * *}$ \\
Work experience & 2 & 2.29 & 0.1 \\
Location & 1 & 0.98 & 0.32 \\
Home language & 2 & 8.45 & $0.0003^{* * *}$ \\
Importance of pine & 1 & 1.46 & 0.23 \\
Importance of eucalypts & 1 & 0 & 0.96 \\
Importance of wattle & 1 & 0.46 & 0.5 \\
Presence of Sirex woodwasp in working area & 1 & 1.48 & 0.23 \\
& & & \\
S. noctilio awareness media & & & \\
Posters & 1 & 4.18 & $0.042^{*}$ \\
Pamphlets or pest cards & 1 & 4.9 & $0.028^{*}$ \\
Articles in TPCP / ICFR newsletters & 1 & 3.72 & 0.055 \\
Internet or website & 1 & 1.05 & 0.31 \\
Magazines or newspapers & 1 & 9.89 & $0.0019^{* *}$ \\
Field days & 1 & 12.25 & $0.0006^{* *}$ \\
Conferences & 1 & 10.87 & $0.0011^{* *}$ \\
Other & 1 & 8.33 & $0.0043^{* *}$
\end{tabular}

*significant at $5 \%$ level, $p<0.05$

**significant at $1 \%$ level, $p<0.01$

${ }^{* * *}$ significant at $0.1 \%$ level, $p<0.001$

Table 7. Correlation between knowledge and perception of general forestry pests and knowledge of $S$. noctilio.

General pest knowledge Importance of impact of forestry pests Importance of research on forestry pests Importance of monitoring for presence of forestry pests

$r_{k}=$ Kendall Tau Correlation Coeffecient

\begin{tabular}{lll}
$r_{k}$ & $p$ value & $n$ \\
\hline 0.32 & $<0.0001$ & 236 \\
-0.028 & 0.57 & 236 \\
0.079 & 0.12 & 236 \\
0.023 & 0.66 & 236
\end{tabular}


Table 8. Division of mother tongue groups by percentage of different job opportunities represented in each group

\begin{tabular}{llllll} 
& $\begin{array}{l}\text { Contractor } / \\
\text { Private }\end{array}$ & $\begin{array}{l}\text { Plantation } \\
\text { managment }\end{array}$ & Researcher & $\begin{array}{l}\text { Senior } \\
\text { management }\end{array}$ & All \\
\cline { 2 - 5 } Afrikaans & $10 \%$ & $63 \%$ & $8 \%$ & $19 \%$ & $100 \%$ \\
English & $17 \%$ & $36 \%$ & $26 \%$ & $21 \%$ & $100 \%$ \\
Other & $23 \%$ & $60 \%$ & $8 \%$ & $9 \%$ & $100 \%$
\end{tabular}

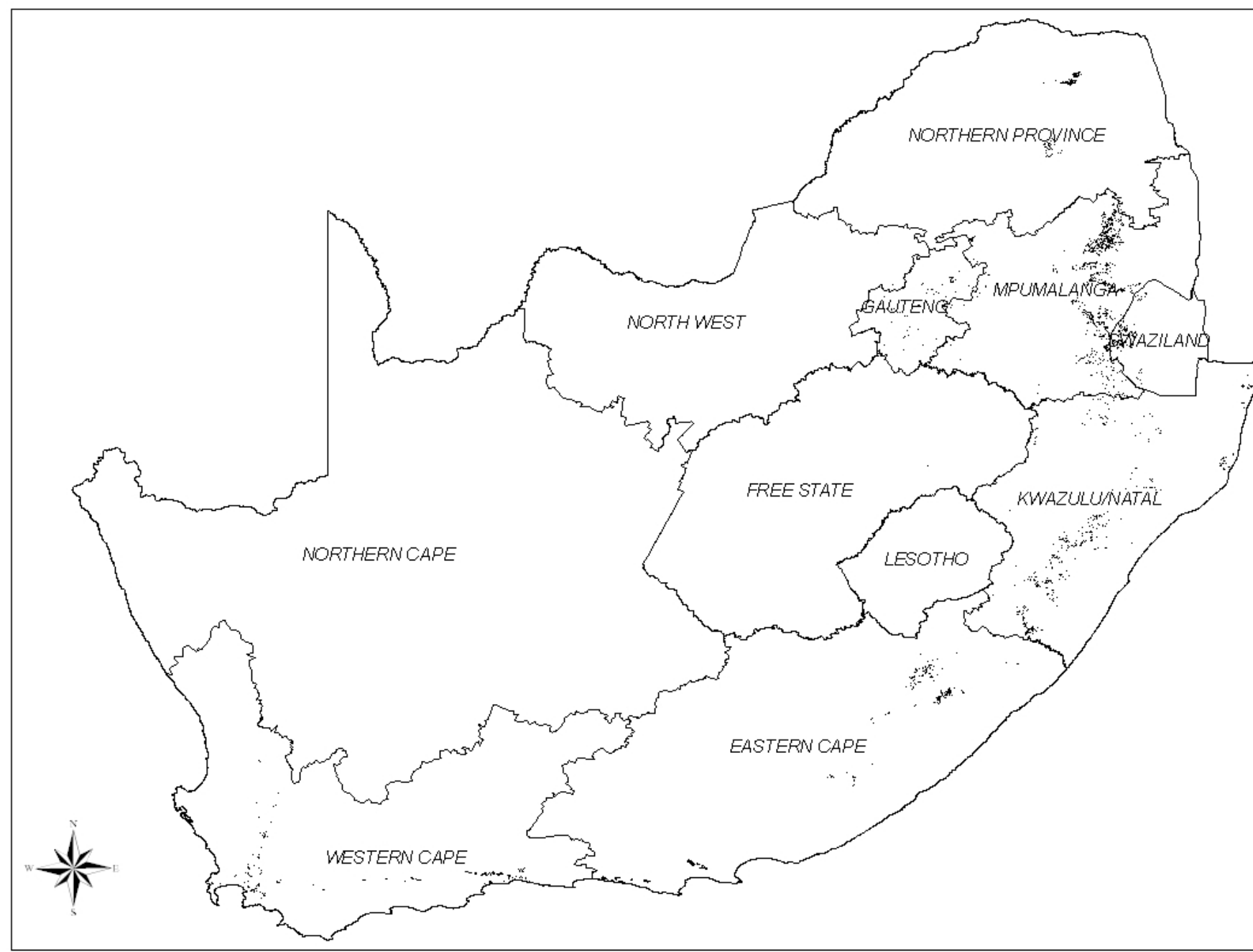

Figure 1. Map of South Africa, showing provinces and pine plantation distribution (in black) 


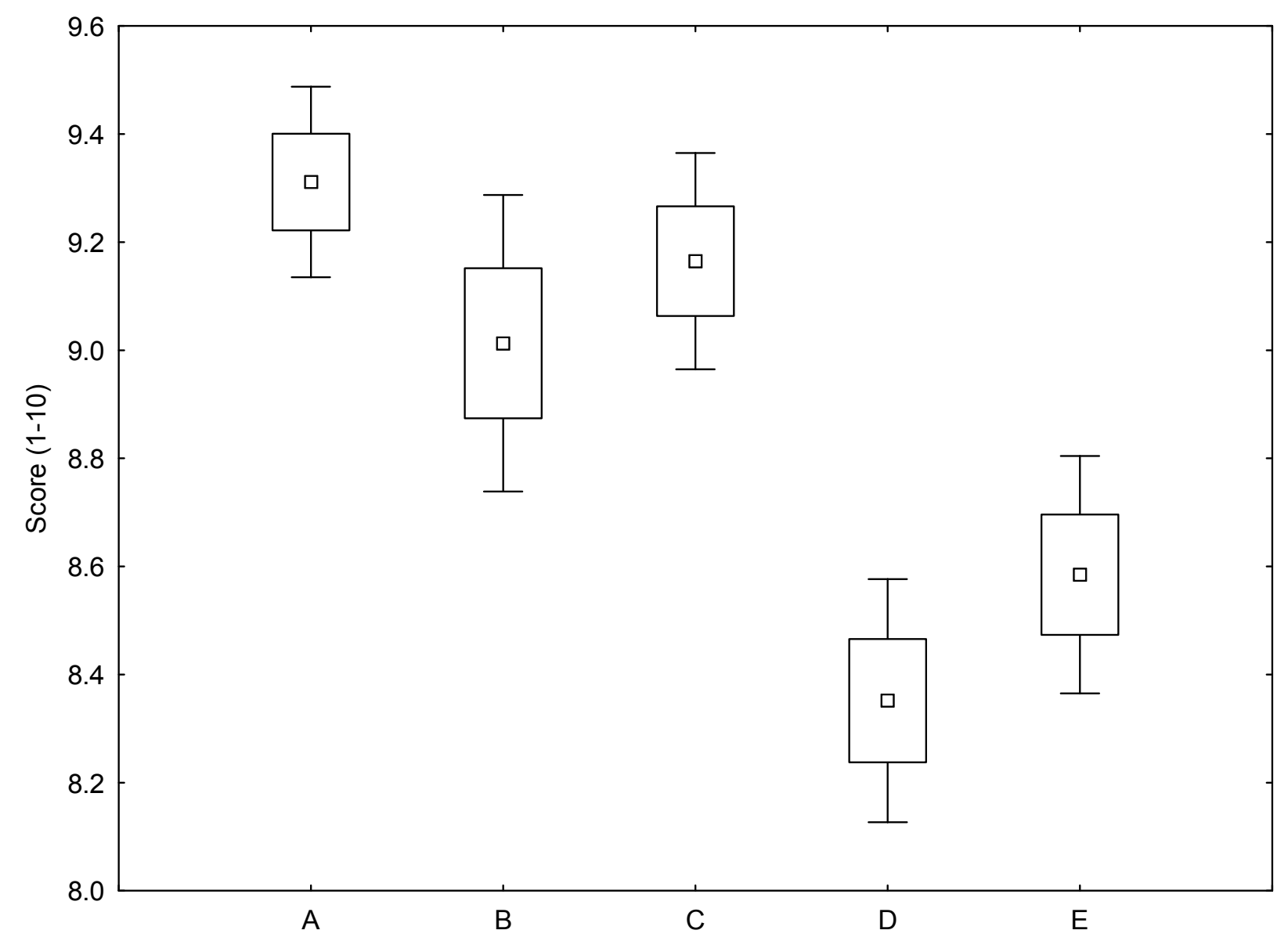

Figure 2. Perception of $S$. noctilio, as scored on a scale of 1-10, with one being not important and 10 being very important. A. Importance of nematodes to control $S$. noctilio. B. Importance of parasitic wasps to control S. noctilio. C. Importance of plantation management to control S. noctilio. D. Seriousness of S. noctilio for current forest productivity. E. Seriousness of S. noctilio for future forest productivity. Small squares show mean, large squares show standard error and error bars show 95\% confidence levels. 
Appendix 1. Questions on Sirex knowledge (refer to Table 1)

Questions

Which tree is attacked by the Sirex woodwasp in South Africa? What age trees are attacked by the Sirex woodwasp in South Africa? What colour is the body of the Sirex female wasp?

What is the distinguishing characteristic of the Sirex larva?

Which one of the following is not correct? A tree attacked by the Sirex woodwasp can show the following symptoms?

Indicate with a yes or no, in which pine-growing provinces the Sirex woodwasp has been detected.

Indicate with a yes or no, in what ways can Sirex spread to other areas.

Are you aware of parasitic nematodes used to control the Sirex woodwasp in South Africa?

Are you aware of plantation management used to control the Sirex woodwasp in South Africa?

Are you aware of parasitic wasps used to control the Sirex woodwasp in South Africa?
Scale / categories

multiple choice

multiple choice

multiple choice

multiple choice

Yes / No

Yes / No (5 options /

questions)

Yes / No (4 options /

questions)

Yes / No

Yes / No

Yes / No 